\title{
Geriatric medical humanities: fresh insights into ageing and geriatric medicine
}

\author{
D. O’Neill ${ }^{1}$ (1)
}

Received: 21 March 2019 / Accepted: 2 April 2019 / Published online: 10 April 2019

(c) European Geriatric Medicine Society 2019

Geriatricians differ from the broader grouping of gerontologists in that they are the discipline most likely to be in daily contact with older people [1]. This is simultaneously a strength and a weakness: a strength in that they are in constant contact with the reality of being an older person, and a weakness in that this is largely confined to those with usually complex healthcare needs. The healthcare paradigm means that our discourse may consciously or unconsciously reflect a failure model of ageing [2], and we may be less aware of the broader experience of ageing in increasingly healthy and growing populations of older people.

However, despite prominent ageism within healthcare and society at large, and perceptions of lower prestige and earning potential of geriatric medicine by medical students within such systems [3], geriatricians consistently report high levels of satisfaction with their work [4]. There may be several factors involved: geriatric medicine has highly effective methodologies [5], it is intellectually stimulating with many under-explored areas of research, involves team working, and in particular engages with life at the richest and most intriguing stage [6].

The richness of later life, and the many benefits of the longevity dividend [7], are perhaps the areas where the professional discourse of geriatric medicine is most impoverished. The consequences of this are important, as they may hinder not only our own identification with, and understanding of, ageing, our appreciation of the importance of our professional mission as guardians of the longevity dividend, and hamper our advocacy efforts with older people and other sections of society [8].

While some degree of insight into the broader context of ageing can be gained from exposure to the other branches of gerontology (social, psychological and biological) during

D. O'Neill

doneill@tcd.ie

1 Centre for Ageing, Neuroscience and the Humanities, Trinity College Dublin, Dublin 2, Ireland undergraduate and postgraduate training [1], it is clear that these elements of gerontology are also increasingly frustrated by how their methodologies may obscure the wider meanings of later life [9]. It is also notable that geriatricians rarely explore the meaning of ageing in their own lives and may express ambivalence about ageing in their research paradigms [8].

A helpful new approach is to blend medical humanitieswhose key aim is to foster a better understanding of what it is to be human, well, ill and to experience the healthcare system through the fields of humanities and the arts [10] — with the evolving field of cultural gerontology, also described as humanities and ageing in North America [11]. As described by a leader in the field [9], cultural gerontology can be described as a tendency, or a field, with a central focus on meaning, a desire to transcend old paradigms, and to bring a fuller, richer account of later years than heretofore presented in gerontology and geriatric medicine.

Given the arguable case that medicine is one of the humanities [10], that the humanities aspect of medicine has been observed for millennia, and that the discourse of the medical humanities has been increasingly formalized over 50 years, prompted by the pioneering work of Pellegrino [12], it might be expected that a synergy between the medical humanities and cultural gerontology might be a good starting point for development of techniques and methodology in cultural gerontology. Surprisingly, of the two key textbooks in cultural gerontology, one makes no reference to medical gerontology [13], and the other includes a very modest contribution [11].

The general medical, and very occasionally geriatric medical, journals have made space for ageing as a focus in their medical humanities rubrics, allowing for reflection on the rich phenomenology of ageing through late-life creativity in art, literature [14], theatre [15], film [16], music [17] and poetry [18]. Cultural gerontology also facilitates an appreciation of the vital impulses present in diseases and 
syndromes of later life, such as dementia [19], stroke [20] and senile squalor [21].

Further developing the medical humanities for geriatric medicine represents an important addition to our repertoire and articulacy, facilitating participation in important trends such as reframing aging, an initiative to emphasize the positivities and worth of later life [22]. It is also a valuable tool for teaching gerontology and geriatric medicine at undergraduate and postgraduate levels [7], and has a helpful pedigree in geriatric medicine in the pioneering work of Robert N. Butler [23].

The editorial board of European Geriatric Medicine considers that the innovative and international policies of the journal lend itself to hosting the first regular journal rubric in geriatric medical humanities in a geriatric medical journal. We invite scholarly reflections on the intersection between geriatric medicine and the medical humanities which provide insight into the nature and meaning of well-being, illness and experiences of the healthcare system in the context of ageing. Focussing on a relevant cultural item-for example, from cinema, theatre, art or literature-these pieces should be written so as to attract the attention of the general readership of European Geriatric Medicine. The word count should be no greater than 1000 words, and contain no more than five references: all submissions will receive peer-review. We are confident that the dynamic and inventive nature that characterizes geriatricians will result in a lively, entertaining, thoughtful, and occasionally controversial, addition to the scholarship of geriatric medicine.

\section{Compliance with ethical standards}

Conflict of interest The author declares that he has no conflict of interest.

Ethical approval This article does not contain any studies with human participants or animals performed by any of the authors.

Informed consent For this type of study formal consent is not required.

\section{References}

1. O'Neill D (2012) Am I a gerontologist or geriatrician? J Am Geriatr Soc 60(7):1361-1363

2. Kalish RA (1979) The new ageism and the failure models: a polemic. Gerontologist 19:398-402
3. Robbins TD, Crocker-Buque T, Forrester-Paton C, Cantlay A, Gladman JR, Gordon AL (2011) Geriatrics is rewarding but lacks earning potential and prestige: responses from the national medical student survey of attitudes to and perceptions of geriatric medicine. Age Ageing 40(3):405-408

4. Leigh JP, Tancredi DJ, Kravitz RL (2009) Physician career satisfaction within specialties. BMC Health Serv Res 9:166

5. Ellis G, Gardner M, Tsiachristas A, Langhorne P, Burke O, Harwood RH et al (2017) Comprehensive geriatric assessment for older adults admitted to hospital. Cochrane Database Syst Rev 9:CD006211

6. Jewell AJ (2014) Tornstam's notion of gerotranscendence: reexamining and questioning the theory. J Aging Stud 30:112-120

7. O'Neill D (2011) The art of the demographic dividend. Lancet 377(9780):1828-1829

8. O’Neill D (2016) Do geriatricians truly welcome ageing? Age Ageing 45(4):439-441

9. Twigg J, Martin W (2014) The challenge of cultural gerontology. Gerontologist 55(3):353-359

10. O’Neill D, Jenkins E, Mawhinney R, Cosgrave E, O’Mahony $\mathrm{S}$, Guest $\mathrm{C}$ et al (2016) Rethinking the medical in the medical humanities. Med Hum 42(2):109-114

11. Cole TR, Ray RE, Kastenbaum R (2010) A guide to humanistic studies in aging: what does it mean to grow old? Johns Hopkins University Press, Baltimore, p 390

12. Pellegrino ED (1969) Human values and the medical curriculum: an educator's response. JAMA 209(9):1349-1353

13. Twigg J, Martin W (2015) Routledge handbook of cultural gerontology. Routledge, London

14. Cotter PE, Wilkinson C, Canavan M, O'Keeffe ST (2011) Language change with aging in Pelham Grenville Wodehouse and George Bernard Shaw. J Am Geriatr Soc 59(8):1567-1568

15. O'Neill D (2015) Ars longa, vita longa. Lancet 385(9973): 1064

16. O'Neill D (2012) How dementia tests Thatcher's mettle. BMJS 344:e378

17. O’Neill D (2010) Metamorphosen. BMJ 341:c5975

18. Jones RL (1999) Old yeats, "the eagle". Lancet 354(Suppl 3):SIII34-SIII7

19. Canavan M, O’Neill D (2010) Barney's version. Br Med J 341:c4561

20. Huf V, O’Neill D (2005) Oskar Kokoschka and Auguste Forel: life imitating art or a stroke of genius? Stroke J Cereb Circ 36(9):2037-2040

21. Ali K (2005) The death of Mr. Lazarescu. Bmj 331(7526):1209

22. Lundebjerg NE, Trucil DE, Hammond EC, Applegate WB (2017) When it comes to older adults, language matters: Journal of the American Geriatrics Society adopts modified American Medical Association Style. J Am Geriatr Soc 65(7):1386-1388

23. Butler RN (1963) The life review: an interpretation of reminiscence in the aged. Psychiatry 26:65-76

Publisher's Note Springer Nature remains neutral with regard to jurisdictional claims in published maps and institutional affiliations. 